\title{
Bank Capital and Uncertainty
}

\author{
Fabian Valencia
}




\title{
IMF Working Paper
}

Research

\section{Bank Capital and Uncertainty}

Prepared by Fabian Valencia ${ }^{1}$

Authorized for distribution by Stijn Claessens

September 2010

\begin{abstract}
This Working Paper should not be reported as representing the views of the IMF. The views expressed in this Working Paper are those of the author(s) and do not necessarily represent those of the IMF or IMF policy. Working Papers describe research in progress by the author(s) and are published to elicit comments and to further debate.

An important role for bank capital is that of a buffer against unexpected losses. As uncertainty about these losses increases, the theory predicts an increase in the optimal level of bank capital. This paper investigates this implication empirically with U.S. Commercial Banks data and finds statistically significant and robust evidence supporting it. A counterfactual experiment suggests that a decline in uncertainty to the lowest level measured in the sample generates an average reduction in bank capital ratios of slightly over 1 percentage point. However, I also find suggestive evidence that the intensity of this precautionary motive is stronger during recessions. From a policy perspective, these results suggest that the effectiveness of countercyclical capital requirements during bad times will be undermined by banks desire to hold more capital in response to increased uncertainty.
\end{abstract}

JEL Classification Numbers:C61, E32, E44

Keywords: Banking, Banking Capital, Risk, Uncertainty

Author's E-Mail Address: fvalencia@imf.org

\footnotetext{
${ }^{1}$ The author thanks Larry Ball, Allen Berger, Christopher Carroll, Stijn Claessens, Jon Faust, and Diana Hancock for comments and discussions. This paper was started while the author was an intern at the Research and Statistics Division of the Board of Governors of the Federal Reserve System. First version 2006.
} 
Contents

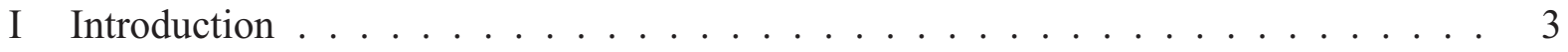

II Theoretical Framework . . . . . . . . . . . . . . . . . . . . 4

A A theoretical measure of uncertainty .............. 6

III Empirical Strategy . . . . . . . . . . . . . . . . . . . 7

A Measuring Uncertainty . . . . . . . . . . . . . . 7

B Estimation Strategy . . . . . . . . . . . . . . . . . 8

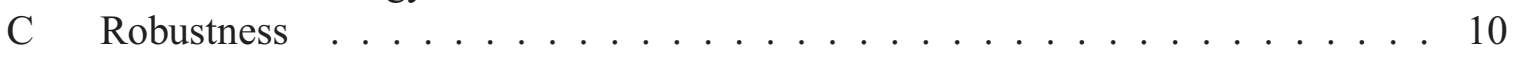

IV Quantitative Importance . . . . . . . . . . . . . . . . . . . 10

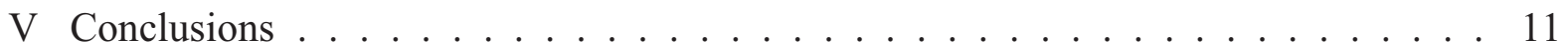

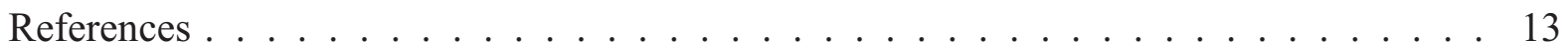

Tables

1 REPP per Group and Overall . . . . . . . . . . . . . . . . . . . . 19

2 Estimation Output . . . . . . . . . . . . . . . . . . . 20

3 Estimation Output . . . . . . . . . . . . . . . . 21

4 Estimation output for different cross-sections . . . . . . . . . . . . . 22

Figures

1 Model-implied Capital-to-Assets Ratio and REPP . . . . . . . . . . . . . 15

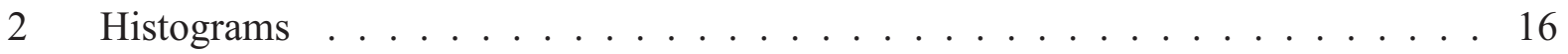

3 Effects of a Reduction in Uncertainty . . . . . . . . . . . . . . . . . . . 17

4 Distribution of Point Estimates in Random Samples . . . . . . . . . . . . . . 18 


\section{INTRODUCTION}

Much of the financial crisis that started with the collapse of the Subprime mortgage market in the United States is blamed on excessive leverage in the economy. However, the causes for this increase in leverage are still under debate since no factor can be singled out as the only cause.

In the particular case of financial institutions, understanding why leverage increased requires first identifying what the key determinants of their optimal capital structure are. Several advances have emerged in theoretical modeling of the optimal capital structure of banks that shed light on what those determinants are. This literature builds on the idea that capital markets are imperfect, invalidating the implications of the the Modigliani and Miller (1958) theorem. Examples include Van Den Heuvel (2002), Keppo and Peura (2005), Valencia (2008), Estrella (2004), Furfine (2001), and Jokivuolle and Peura (2004). One of the key roles that bank capital serves in some of these models is that of a buffer against unexpected losses, resulting in a precautionary motive. This role for bank capital is widely recognized in the literature, for instance in Hancock and Wilcox (1994a,b), Berger and Udell (1994), and Peek and Rosengren (1995), yet empirical evidence quantifying its importance is scarce.

This precautionary motive implies that when uncertainty is high, banks will find optimal to increase their capital, and viceversa. Thus, periods of low macroeconomic volatility, like the one that preceded the crisis, would be associated with high bank leverage, relative to a period of high volatility. This paper contributes to this literature with a formal empirical test of this precautionary motive.

The point of departure is a simple dynamic model of a lender faced with uncertainty based on Valencia (2008). In the model, the lender self-insures against unexpected losses by holding more capital whenever uncertainty increases. Using this simple model, I derive a theoretical measure of uncertainty borrowed from the precautionary savings literature (Kimball, 1990). I also use simple atheoretical measures of uncertainty as a robustness exercise. The empirical examination is implemented using U.S. commercial banks data for the period 1995-2005.

The empirical analysis results in significant and robust support for the hypothesis that banks facing higher uncertainty also maintain higher capital-to-assets ratios. The results are highly statistically and economically significant. A counterfactual experiment using the baseline estimates suggests that if uncertainty were to decline to the minimum observed in the sample, a weighted average reduction of slightly over 1 percentage point in bank capital ratios would follow. However, I also find suggestive evidence that the sensitivity to uncertainty increases during recessions, suggesting that the economic significance of this effect is stronger during bad times. It is important to keep in mind that this is only one channel through which banks could mitigate the effects of uncertainty. Alternatively, banks can also securitize assets, alter the composition of liabilities, assets, off balance sheet positions, etc. in order to mitigate the effects of uncertainty. Consequently, the results presented in this paper could be interpreted as a lower-bound of the total impact of uncertainty on banks' behavior. 
The empirical results presented in this paper also offer support to recent theoretical contributions on leverage cycles, for instance Fostel and Geanakoplos (2008) and Adrian and Shin (2008), in which reduced volatility imply an increase in leverage. The results have also implications for bank capital regulation. Kashyap and Stein (2004), Jokivuolle and Peura (2004), and others, suggest that an adequate adjustment of capital buffers could be an important mitigating factor of the procyclicality feature of Basel II. More recently, the ongoing debate on the need for countercyclical bank regulation, for instance Crockett, Brunnermeier, Goodhart, Persaud, and Shin (2009), includes the idea of cyclical variation in capital buffers that can be used in bad times and accumulated during good times. The empirical results presented in this paper suggest that these countercyclical tools may turn out to be effective in restraining credit during good times, but may not provide the needed relief during bad times because in those instances banks will want to decrease leverage as a response to increased uncertainty. Calibration of countercyclical regulation would need to factor in this behavior.

The paper is organized as follows: section II presents the theoretical framework. Section III discusses the empirical strategy, how uncertainty is measured, and presents the estimation results. Section IV simulates the effects of a reduction in uncertainty, and section V concludes.

\section{TheORETICAL FrameWORK}

The point of departure for this paper is a variant of the model presented in Valencia (2008). This simple model serves the purpose of motivating the analysis and deriving a theoretical measure of uncertainty.

Consider a bank managed by risk-neutral shareholders who maximize the present discounted value of dividends.

$$
\underset{\left\{c_{s}, l_{s}\right\}_{t}^{\infty}}{\operatorname{Max}} E_{t} \sum_{t=s}^{\infty} \beta^{s-t} c_{s}
$$

where $\beta$ denotes the discount factor, $c_{s}$ denotes dividends, and $l_{t}$ denotes total lending. The bank is also subject to a balance sheet constraint given by

$$
l_{t}=\underbrace{n_{t}-c_{t}}_{q_{t}}+d_{t}
$$

where $d_{t}$ denotes bank debt, $n_{t}$ bank capital, and $q_{t}$ bank capital net of dividends. For simplicity, it is assumed also that bank revenues are uncertain because they are affected by random shocks $\alpha$. One possible microeconomic interpretation of these random shocks is that of the ability of managers in screening and/or monitoring loans. An alternative macroeconomic interpretation is the total impact on bank revenues of fluctuations in asset 
prices, interest rates, productivity, etc. Thus $\alpha_{t+1} r^{L}$ denotes the total ex-post return on loans. Notice that the ex-post return can exceed the expected ex-ante return $r^{L}$, reflecting the realization of uncertainty. For instance, under the manager ability interpretation, a higher ex-post return would reflect high efficiency in borrower screening and/or monitoring. Under the macro interpretation it could reflect better economic conditions than expected. ${ }^{2}$ These conditions together with the balance sheet constraint imply a transition equation for bank capital of the following form:

$$
n_{t+1}=\alpha_{t+1} r^{L} l_{t}-r^{D}\left(l_{t}-q_{t}\right)
$$

where $r_{t}^{D}$ the yield on deposits. The problem, written in Bellman's equation form is given by

$$
\begin{aligned}
V\left(n_{t}\right) & =\underset{\left\{q_{t}, l_{t}\right\}}{\operatorname{Max}}\left[n_{t}-q_{t}+E_{t} \beta V\left(n_{t+1}\right)\right] \\
n_{t+1} & =\alpha_{t+1} r^{L} l_{t}-r_{t}^{D}\left(l_{t}-q_{t}\right) \\
q_{t} & \leq n_{t}
\end{aligned}
$$

The last equation is a restriction on equity financing, reflecting capital market imperfections. It tells us that capital, after distributing dividends, can at most be equal to the capital the bank had at the beginning of the period. While the non-equity financing assumption is extreme, it is made just for simplicity. As long as it is costly to adjust capital, and as long as there are capital market imperfections, the key implication of the model relevant for this paper will still hold. For instance, in Valencia (2010), the bank can issue equity, but shareholders care about dividend smoothing, and the same precautionary motive arises.

One final assumption involves decomposing the yield on deposits into two subcomponents $r_{t}^{D}=\rho+f_{t}$, where $\rho$ is the risk-free rate and $f_{t}$ is a wedge that increases with bank leverage, assumed to be at least twice continuously differentiable. This assumption implies that borrowing costs vary with the bank's capital structure. The assumptions on $f_{t}$ generate increasing marginal costs of borrowing and thus deliver an interior solution. It is possible to derive $f_{t}$ endogenously, for instance from imposing some form of information asymmetries between creditors and the bank. The interaction between these information problems and the bank's risk of default invalidate Modigliani and Miller (1958)'s implications because bank borrowing costs change as bank leverage changes (see Valencia, 2008, for a concrete example). While the model is too simple to yield quantitative implications, it suffices to illustrate the relationship between capital and uncertainty.

The corresponding first order conditions are given by

\footnotetext{
${ }^{2}$ Even if these are aggregate, common shocks to all banks, one could write the model assuming that not all banks hold the same portfolio, with the consequence that macroeconomic fluctuations would affect banks differently.
} 


$$
\begin{aligned}
1 & =\beta E_{t} V^{\prime}\left(n_{t+1}\right)\left[\rho+f_{t}-\left(l_{t}-q_{t}\right) \frac{d f_{t}}{d q}\right] \\
0 & =E_{t} V^{\prime}\left(n_{t+1}\right)\left[\alpha_{t+1} r^{L}-\left(\rho+f_{t}\right)-\left(l_{t}-q_{t}\right) \frac{d f_{t}}{d l}\right]
\end{aligned}
$$

The right hand-side of equation (7) corresponds to the marginal value of holding capital, while the left-hand side, the marginal value of dividends. The amount of dividends distributed is such that both are equal. Equation (8) tells us that the optimal amount of lending is such that expected marginal profits are zero. Notice that lending and dividends decisions depend on the leverage level of the bank through the derivatives of $f_{t}$ with respect to lending and capital, because changes in leverage affect the marginal costs of borrowing.

\section{A. A theoretical measure of uncertainty}

There is no theoretical framework that is widely accepted in the literature as a standard way to measure uncertainty. One theoretically appealing option, however, is Kimball (1990). He develops a theoretical framework which builds on Rothschild and Stiglitz (1971) and applies it to the specific case of precautionary saving in consumption theory. At the empirical level, Carroll and Samwick (1998) employ Kimball (1990)'s framework together with atheoretical measures of uncertainty to quantify the importance of precautionary savings in U.S. data. Kimball (1990)'s measure of interest is the equivalent precautionary premium. In the context of the model presented in this paper, the equivalent precautionary premium is defined as the certain reduction in dividends (or alternatively, the certain increase in capital) that has the same effect on the banks' optimal decisions as adding uncertainty.

Formally, let $q^{*}$ denote the target level of bank capital the bank wishes to hold, and let $\Psi$ denote the equivalent precautionary premium. Assume also for analytical convenience that $f=\left(\frac{l_{t}-q_{t}}{\alpha_{t+1} r^{L} l_{t}}\right) v$ for $v>0$ and denote $l^{*}$ the optimal amount of lending that satisfies equation (8). The definition of the equivalent precautionary premium implies ${ }^{3}$

\footnotetext{
${ }^{3} \mathrm{~A}$ requirement for the problem to have a well-defined solution is that $\beta^{-1}>\rho$. With this assumption, the bank does not have the incentive to accumulate capital forever. This implies that in equilibrium, the non-negativity constraint on dividends does not bind. The Envelope theorem then implies that $1=\frac{d V\left(n_{t+1}\right)}{d n_{t+1}}$ in equilibrium.
} 


$$
\begin{aligned}
\beta E_{t}\left[\rho+2 \frac{l^{*}-q^{*}}{\alpha_{t+1} r^{L} l^{*}} v\right] & =\beta\left[\rho+2 \frac{l^{*}-q^{*}+\Psi}{r^{L} l^{*}} v\right] \\
E_{t}\left[\frac{l^{*}-q^{*}}{\alpha_{t+1} r^{L} l^{*}}\right] & =\left[\frac{l^{*}-q^{*}+\Psi}{r^{L} l^{*}}\right] \\
\left(l^{*}-q^{*}\right) E_{t} \frac{1}{\alpha_{t+1}} & =l^{*}-q^{*}+\Psi \\
E_{t} \frac{1}{\alpha_{t+1}}-1 & =\frac{\Psi}{l^{*}-q^{*}}
\end{aligned}
$$

where the last step gives us a scaleless measure, which from now on will be referred to as the relative equivalent precautionary premium, or simply REPP. Essentially, the non-linearity in $\alpha$ introduced by the assumptions made on $f_{t}$ implies that the variance of the distribution of $\alpha$ matters for the choice of the level of capital generating a precautionary motive, just like a decreasing marginal utility of consumption does it in consumption theory. The realizations of $\alpha$ will ultimate impact bank capital. Therefore, in reduced-form $\alpha$ can simply be seen as unexpected fluctuations in bank capital either because of microeconomic reasons, under the managerial screening/monitoring ability interpretation, or macroeconomic reasons, under the business cycle interpretation.

\section{EMPIRICAL STRATEGY}

This section begins by discussing the data and methodology to measure uncertainty and then it elaborates on the estimation strategy and robustness exercises.

\section{A. Measuring Uncertainty}

The dataset in question is a merger-adjusted dataset, constructed from the Consolidated Reports of Condition and Income-known as CALL reports-of US Banks. The focus of this paper is on the cross-sectional distribution of bank capital ratios, as an approximation to the steady state distribution of bank capital. However, the time dimension of the data is needed to estimate the empirical distribution of bank capital shocks. For this purpose, the paper uses data from 1995 until 2005. As a first step, I construct yearly observations by averaging end-of-quarter balances in order to reduce the impact of seasonal effects. As a second step, I consider only banks that remain active for the entire sample period.

With the data on hand, the next step is to construct an empirical measure of REPP, with the objective of regressing measures of bank capital ratios on REPP. One approach could be to use a long time series on each bank and compute a bank-specific REPP. However, under this approach one would worry about reverse causality because a bank with high capital could choose to take on more risk and thus influence its value of REPP. A way around this problem is to compute REPP at the level of groups of banks, so that an individual bank cannot 
influence the level of REPP of the group. While this approach cannot entirely put all endogeneity concerns at rest, it at least addresses the most obvious one. ${ }^{4}$

For this purpose, I construct groups of banks according to different bank variables, one at a time: size (measured as the natural logarithm of total assets), federal reserve district, exposure to real estate lending (measured as the fraction of loans secured by real estate to total (gross) loans), composition of liabilities (measured as the ratio of total deposits to total liabilities), and off-balance sheet activity, (measured as the ratio of off-balance sheet items to total assets). ${ }^{5}$ These criteria aim at capturing differences in banks' business models. Figure 2 shows histograms for all the variables described.

For each bank variable listed above, the bank groups are deciles of the corresponding variable, except in the case of the federal reserve district. For each group, I first remove the effect of common trends by computing a relative capital-to-assets indicator denoted by $\chi_{t, j i}$, defined as the ratio of $s_{t, j i}$ to $S_{t}$, where the former denotes the capital-to-assets ratio for bank $i$, in year $t$, in group $j$, and the latter denotes the average capital-to-assets ratio in period $t$ for the entire banking industry. With this variable on hand, realizations of $\alpha_{t, j i}$ are computed as $\alpha_{t, j i}=\frac{\chi_{t, j i}}{\chi_{t-1, j i}}$, that is, the change in period t of the capital ratio-normalized by the industry capital ratio-relative to period t-1. Thus there are $\operatorname{Tx} N_{j}$ values of $\alpha$ for each group $j$, where T is the number of years, and $\mathrm{N}$ is the number of banks in group $j$. For each group $j$, the $T x N_{j}$ available points are used to estimate the empirical distribution of $\alpha$ using a 20-point kernel estimator. With the estimated empirical distribution of $\alpha$ I compute REPP following equation (12). Descriptive statistics for these estimated values of REPP are shown in Table 1.

\section{B. Estimation Strategy}

With the data on hand, the objective is to determine how much of the cross-sectional distribution of capital-to-assets ratios can be explained by uncertainty. First, as an illustration of the model implications, I rewrite equation (7) using the fact that in equilibrium, the non-equity financing constraint is not binding

$$
q^{*}=l^{*}\left[1-\left(\frac{\beta^{-1}-\rho}{2 E\left[\alpha^{-1}\right]}\right) r\right]
$$

The above equation can be used to derive a relationship between the capital-to-assets ratio in equilibrium $q * / l *$ and uncertainty, using the various distributions of $\alpha$ estimated according to

\footnotetext{
${ }^{4}$ Ideally, one would like to have an exogenous source of variation in risk that could be used as an identification strategy. However, such a setup, in the case of banking, does not exist.

${ }^{5}$ The sum of off-balance sheet items includes unused commitments, letters of credit (financial, performance, and commercial), acceptances (conveyed and acquired), securities borrowed and lent, financial assets transferred with recourse, credit derivatives, interest rate contracts, foreign exchange contracts, and the account recording other off-balance sheet items
} 
the previously described procedure. ${ }^{6}$ Figure 1 shows the model-implied relationship between optimal capital-to-assets ratio, $q * / l *$, and the various values of REPP that were computed using equation (12) and the estimated empirical distributions of $\alpha$.

The empirical exercise uses a linear specification of the following form:

$$
s_{i}=\alpha_{0}+\alpha_{1} R E P P_{i}+\alpha_{2} X_{i}+\epsilon_{i}
$$

Where $s_{i}$ denotes the capital-to-assets ratio of bank $i$ measured as of the mid-point of the sample period (year 2000). Robustness exercises will show later that selecting a different year for the cross-sectional regressions do not alter the conclusions. $R E P P_{i}$ is the average REPP for bank $\mathrm{i},{ }^{7} X_{i}$ is a vector of control variables, and $\epsilon_{i}$ is a zero-mean random disturbance. For estimation purposes, the regressions exclude banks with capital-to-asset ratios outside the 1st and 99 th percentile range.

The vector of controls, $X_{i}$, includes all the variables described earlier, which were employed in classifying banks for the computation of REPP. Recall that these variables aim at approximating the business model of a bank. They include dummies for Federal Reserve Districts, the natural logarithm of total assets, the fraction of deposits to total liabilities; the ratio of loans secured with Real Estate to gross total loans, and the ratio of off-balance sheet items to total assets. All these variables, except for the Federal Reserve District dummies, have been lagged once to address concerns of reverse causality. An omitted variables bias is less of a concern because of the way REPP is constructed, since the variable would have to be correlated with REPP for it to be of significant concern.

An alternative measure of uncertainty used in the estimation is the variance of the capital-to-assets ratio denoted as VARCAR, but computed in the same way as REPP, that is, by splitting the sample of banks into deciles according to one variable at a time, and computing VARCAR for each group. Equation (14) is then estimated with VARCAR instead of REPP, as a robustness experiment.

Table 2 shows the estimation results. The coefficient on REPP comes up highly statistically significant in all specifications shown in the table and with the expected sign, confirming an statistically important role for bank capital as a buffer against unexpected losses. Of the remaining variables, it is interesting to note that size is statistically significant and positive, suggesting that larger institutions hold more capital, after controlling for uncertainty and the other variables included in the regression. The importance of off-balance sheet activity comes

\footnotetext{
${ }^{6}$ I do not obtain a full numerical solution of the model because I will not be using the model to simulate dynamics or derive quantitative implications. However, in solving for $q^{*}$, the following calibration is used: $\rho$ $=2.5 \%, \mathrm{r}=5 \%$, and $\beta$ is chosen as to generate capital-to-asset ratios similar to those seen in the data.

${ }^{7}$ REPP is estimated for bank groups, therefore, each bank will appear in each of the 5 groups I have constructed. Ideally, one would subdivide the data many more times; however, given the available data, one looses accuracy in the estimation of the kernels. The subdivisions done, therefore are done as to ensure a reasonable minimum number of observations in each group. The average REPP for bank $i$ is then the mean of all its corresponding values of REPP.
} 
up statistically significant and negative. As banks' off-balance sheet activity grows in importance, capital ratios decline and a similar pattern arise when looking at the results for real estate lending. This may be driven by either regulatory reasons, or lower risk-perceptions by banks of engaging in these activities. The composition of liabilities does not come up significant, ceteris paribus. The Federal Reserve District dummies come up all positive but not always statistically significant, except for Boston which comes up statistically significant and negative.

Table 3 shows the same regression, but with VARCAR instead of REPP. ${ }^{8}$ The results are qualitatively similar, and again, the measure of uncertainty comes up highly statistically significant and positive.

\section{Robustness}

I now consider several robustness exercises. First, I estimate equation (14) in 1000 random subsamples, each comprising 80 percent of banks included in the dataset. Figure 4 shows the histogram of point estimates for the coefficient on REPP, with a high concentration around the baseline estimate.

Recall that the regressions are performed as of year 2000, given the choice of selecting the mid-point of the 10-year range of data over which the empirical distribution of capital shocks is computed. The last robustness check involves choosing different years, using the cross-sectional distribution as of 1998 through 2002, one year at a time. The results are shown in Table 4. The resulting point estimates for the coefficient on REPP remain in the range 0.34-0.54 and statistically significant, consistent with the baseline estimates. However, it is interesting to see how the value of the coefficient peaks in 2001, precisely a year of a recession, suggesting that the intensity of the precautionary motive increases in bad times. A more rigorous analysis of this interesting suggestive evidence would require isolating two possible situations: an increase in the intensity of the precautionary motive, holding perceived risk constant, or a decrease in perceived risk, holding the attitude towards risk constant. I leave this task for future research.

\section{QUANTITATIVE IMPORTANCE}

How would the cross-sectional distribution of bank capital-to-asset ratios would change if uncertainty declined for all banks? The experiment is implemented by computing the magnitude by which banks would decrease bank capital holdings if uncertainty declined to the

\footnotetext{
${ }^{8}$ similar regressions with the volatility of loan growth and the volatility of the change in the capital-to-assets ratio yield similar results.
} 
lowest level observed in the sample, keeping everything else equal. ${ }^{9}$ This exercise is performed by computing equation (15)

$$
\Delta s_{i}=\hat{\alpha}_{1} *\left[R E P P_{i}-R E P P_{\min }\right]
$$

where $\Delta s_{i}$ denotes the change in the capital-to-assets ratio for bank $i$ that would result if uncertainty-measured by REPP-were to decline to the minimum level observed in the sample, $R E P P_{\min }$. The parameter $\hat{\alpha_{1}}$ corresponds to the point estimate shown in column 6 of Table 2. Figure 3 plots the histogram corresponding to the reduction in bank capital-to-asset ratios, in percentage points.

For convenience, the graph also shows the weighted average reduction in bank capital ratios. The experiment shows that the simulated decrease in uncertainty would, on a weighted average basis, reduce bank capital-to-assets ratios by slightly over 1 percentage point. The reductions are concentrated in the $0-1$ range, with some banks reducing bank capital ratios in more than 1.5 percentage points. The finding discussed earlier on the sensitivity of bank-capital-ratios to uncertainty being higher in 2001 suggests that the quantitative importance of this behavior is more important during recessions than the 1 percentage point average result obtained under the baseline estimates.

\section{Conclusions}

Many factors contributed to the unfolding of the financial crisis that started in 2007 with the collapse of the subprime mortgage market in the United States. One salient factor often blamed for the crisis is the excessive leverage in the economy that led to the accumulation of significant risks, ultimately unraveling in the crisis we are all familiar with.

In understanding how leverage plays a role, it is important as first step to understand how leverage decisions are made, and many theoretical contributions have actually shed light on what the determinants of financial institutions' leverage decisions are. In a number of these studies, a common implication is that uncertainty or volatility leads to a decrease in leverage. This paper contributes with an empirical test of this implication using U.S. commercial banks data.

Estimation of an equation relating capital-to-assets ratios to uncertainty measures suggest a highly statistically significant and robust effect of uncertainty on bank capital. Banks facing higher uncertainty also keep higher capital-to-assets ratios after controlling for different bank characteristics. The empirical evidence is robust to the use of theoretical and atheoretical

\footnotetext{
${ }^{9}$ Shutting down uncertainty completely would not be correct because it would involve a significant regime change, for which the estimated coefficients may not be valid because of the Lucas critique. Moreover, the exercise considers only changes in the cross-sectional distribution of bank capital to minimize the impact of a Lucas critique type of problem. In this way, given some initial distribution of bank capital, the calculation can be interpreted as by how much the steady state amount of capital would change.
} 
measures of uncertainty and other robustness checks. Moreover, a counterfactual experiment suggests that if uncertainty declined to the minimum level measured in the sample, capital to assets ratios would on average decline in slightly over 1 percentage point, with some banks reducing capital-to-assets ratios in over 1.5 percentage points. However, I also find suggestive evidence that the sensitivity to uncertainty increases during recessions. A more rigorous exploration of this result is left for future research. Given that banks have alternative means, other than increasing capital, to mitigate uncertainty, the results presented here are only a lower bound of the total effect of uncertainty on banks' behavior.

From a policy perspective, the results presented in this paper suggest that countercyclical bank regulatory requirements-be it in the form of capital or provisions-may be effective in good times when banks want to increase leverage in response to decreased uncertainty, but they may be less effective in bad times, when banks wish to decrease leverage. 


\section{References}

Adrian, Tobias and Hyun Shin, 2008, "Financial Intermediaries, Financial Stability, and Monetary Policy,” Federal Reserve Bank of New York Staff Report 346.

Berger, Allen and Gregory Udell, 1994, "Did Risk-Based Capital Allocate Bank Credit and Cause the Credit Crunch in the United States?," Journal of Money, Credit and Banking, 26(3), 585-628.

Carroll, Christopher and Andrew Samwick, 1998, "How Important Is Precautionary Saving?" Review of Economics and Statistics, 80(3), 410-19.

Crockett, Andrew, Markus Brunnermeier, Charles Goodhart, Avinash Persaud, and Hyun Shin, 2009, "The Fundamental Principles of Financial Regulation," Geneva Reports on the World Economy 11, Centre for Economic Policy Research.

Estrella, Arturo, 2004, "The Cyclical Behavior of Optimal Bank Capital," Journal of Banking and Finance, (28), 1469-98.

Fostel, Ana, and John Geanakoplos, 2008, "Leverage Cycles and the Anxious Economy," American Economic Review, 98(4), 1211-44.

Furfine, Craig, 2001, "Bank Portfolio Allocation: The Impact of Capital Requirements, Regulatory Monitoring, and Economic Conditions," Journal of Financial Services Research, 1(20), 33-56.

Hancock, Diana and James Wilcox, 1994a, "Bank Capital and the Credit Crunch: The Roles of Risk-Weighted and Unweighted Capital Regulations," Journal of the American Real Estate and Urban Economics Association, 22(I), 59-94.

Hancock, Diana and James Wilcox, 1994b, "Bank Capital, Loan Delinquencies, and Real Estate Lending," Journal of Housing Economics, 3, 121-46.

Jokivuolle, Esa and Samu Peura, 2004, "Simulation-based Stress Tests of Banks Regulatory Capital Adequacy," Journal of Banking and Finance, 28, 1801-24.

Kashyap, Anil and Jeremy Stein, 2004, "Cyclical Implications of the Basel II Capital Standards," Economic Perspectives, QI, 18-31.

Keppo, Jussi and Samu Peura, 2006, "Optimal Bank Capital with Costly Recapitalization," Journal of Business, 79, 2163-2202.

Kimball, Miles, 1990, "Precautionary Saving in the Small and in the Large," Econometrica, 58(1), 53-73.

Modigliani, Franco and Merton Miller, 1958, "The Cost of Capital, Corporation Finance and 
the Theory of Investment," American Economic Review, 48(3), 261-97.

Peek, Joe and Eric Rosengren, 1995, "Bank regulation and the Credit Crunch," Journal of Banking and Finance, 19(3-4), 679-92.

Rothschild, Michael and Joseph Stiglitz, 1971, "Increasing risk II: Its Economic Consequences," Journal of Economic Theory, 3, 66-84.

Valencia, Fabian, 2008, "Banks' Buffer Capital and Credit Crunches," Working paper 08/248, International Monetary Fund.

Valencia, Fabian, 2010, "Bank Leverage, Monetary Policy, and Financial Stability," mimeo, International Monetary Fund.

Van Den Heuvel, Skander, 2002, "The Bank Capital Channel of Monetary Policy," University of Pennsylvania mimeo. 
Figure 1. Model-implied Capital-to-Assets Ratio and REPP

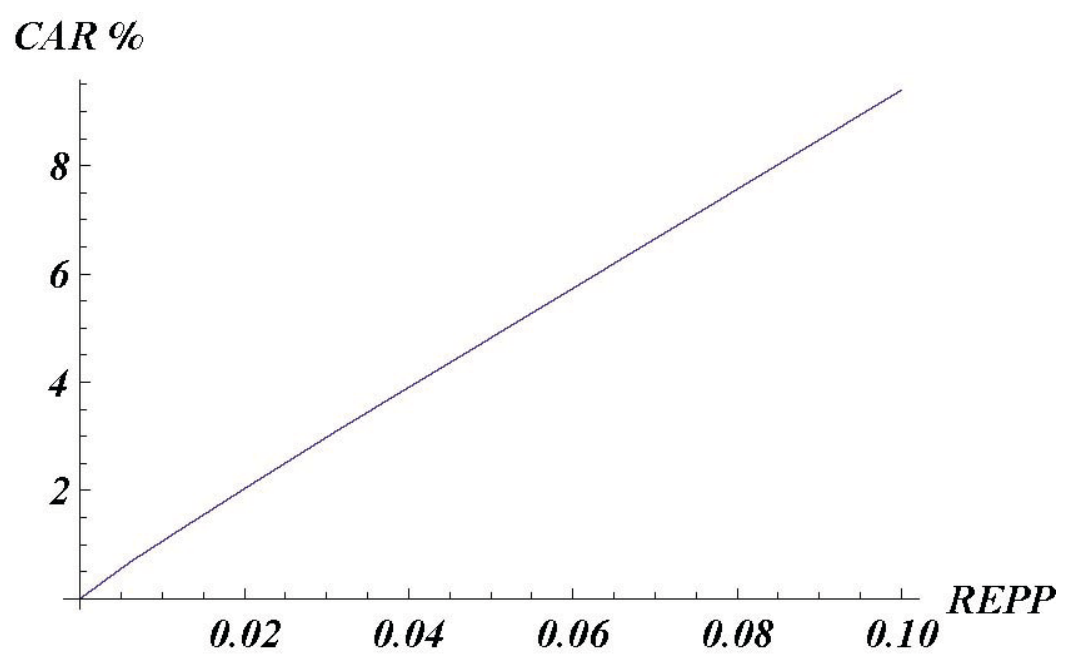


Figure 2: Histograms

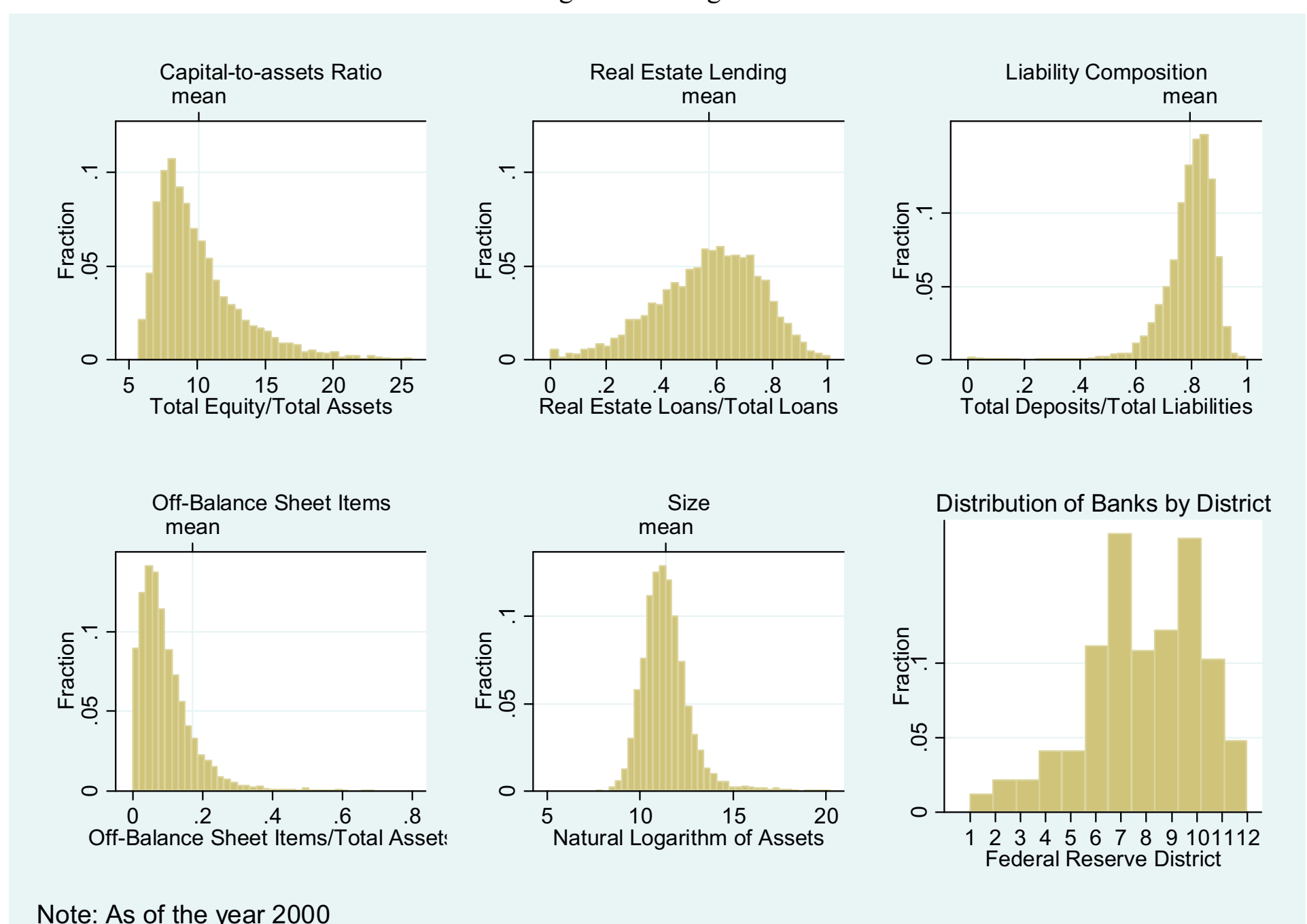

Note: As of the year 2000

Note: $1=$ Boston, $2=$ New York, $3=$ Philadelphia, $4=$ Cleveland, 5=Richmond, $6=$ Atlanta, $7=$ Chicago, $8=$ St.Louis, $9=$ Minneapolis $10=$ Kansas City, 11=Dallas, 12=San Francisco 
Figure 3: Effects of a Reduction in Uncertainty

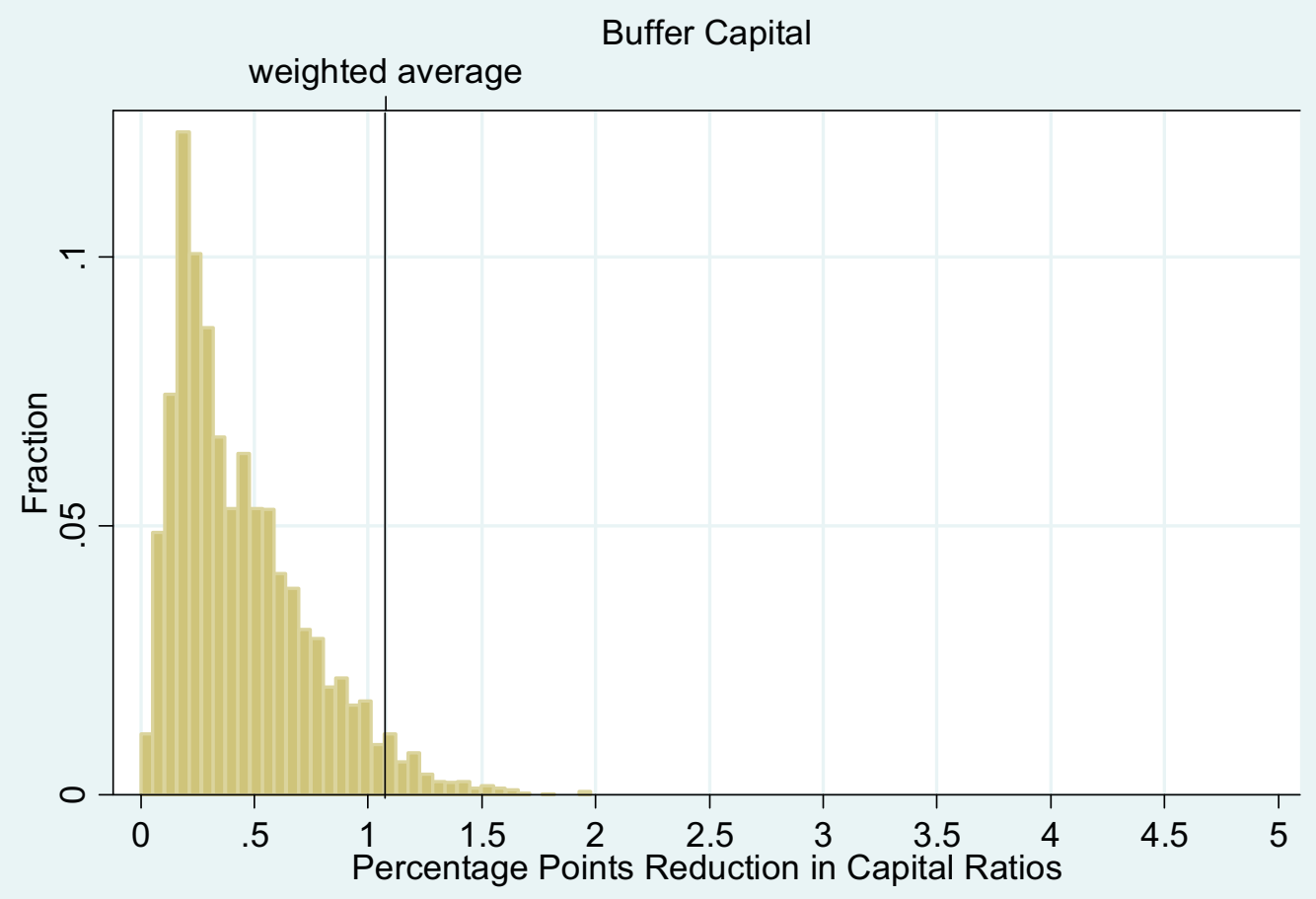


Figure 4: Distribution of Point Estimates in Random Samples

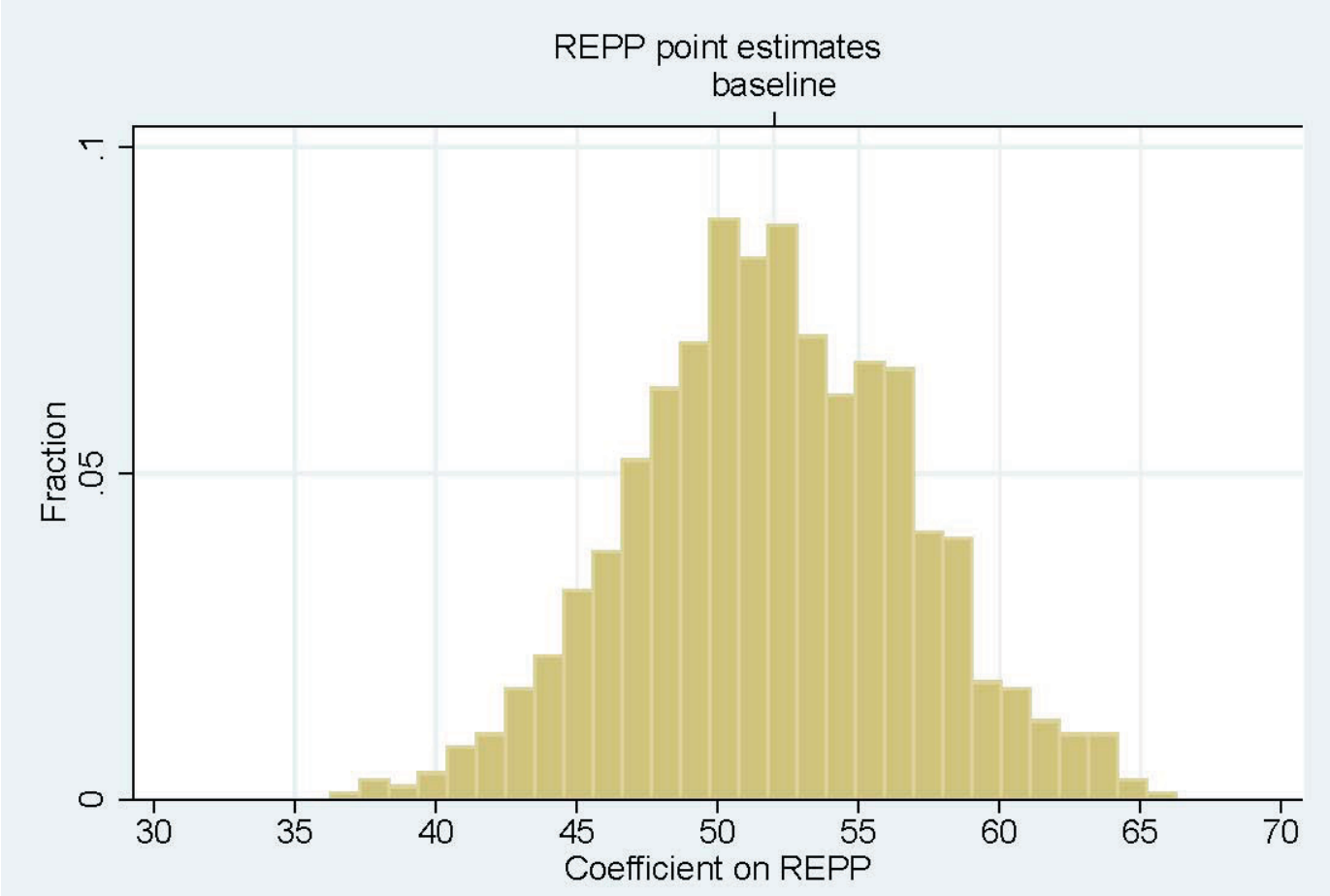


Table 1: REPP per Group and Overall

\begin{tabular}{lccccc}
\hline Category & \multicolumn{5}{c}{ Summary Statistics } \\
\cline { 2 - 6 } & Number of Observations & Mean & Std. Deviation & Min & Max \\
Size & 68607 & 1.50 & 0.87 & 0.74 & 3.21 \\
Federal Reserve District & 68607 & 1.30 & 1.08 & 0.60 & 5.77 \\
Off-balance sheet activity & 68607 & 1.55 & 1.20 & 0.56 & 4.27 \\
Real Estate Lending & 68607 & 1.70 & 1.35 & 0.75 & 5.11 \\
Composition of liabilities & 68607 & 1.47 & 1.01 & 0.56 & 4.20 \\
Overall & 68607 & 1.52 & 0.59 & 0.65 & 4.47 \\
\hline
\end{tabular}


Table 2: Estimation Output

\begin{tabular}{|c|c|c|c|c|c|c|}
\hline \multirow[b]{2}{*}{ Independent Variables } & \multicolumn{6}{|c|}{ Dependent Variable: Capital-to-assets Ratio ${ }^{a}$} \\
\hline & $(1)$ & $(2)$ & (3) & (4) & $(5)$ & $(6)$ \\
\hline Constant & $\begin{array}{c}9.53 * * * \\
(0.122)\end{array}$ & $\begin{array}{c}8.79 * * * \\
(0.404)\end{array}$ & $\begin{array}{c}8.81 * * * \\
(0.405)\end{array}$ & $\begin{array}{c}9.21 * * * \\
(0.576)\end{array}$ & $\begin{array}{c}9.24 * * * \\
(0.628)\end{array}$ & $\begin{array}{c}8.72 * * * \\
(0.682)\end{array}$ \\
\hline REPP & $\begin{array}{c}38.37 * * * \\
(8.27)\end{array}$ & $\begin{array}{c}38.61 * * * \\
(8.27)\end{array}$ & $\begin{array}{c}38.65 * * * \\
(8.27)\end{array}$ & $\begin{array}{c}38.39 * * * \\
(8.28)\end{array}$ & $\begin{array}{c}37.88^{* * * *} \\
(8.32)\end{array}$ & $\begin{array}{c}51.86^{* * *} \\
(9.65)\end{array}$ \\
\hline Size, $\ln$ (assets) & & $\begin{array}{c}0.06^{*} \\
(0.033)\end{array}$ & $\begin{array}{c}0.06^{*} \\
(0.033)\end{array}$ & $\begin{array}{c}0.06 \\
(0.035)\end{array}$ & $\begin{array}{l}0.07 * * \\
(0.037)\end{array}$ & $\begin{array}{c}0.07 * \\
(0.037)\end{array}$ \\
\hline Off-balance sheet activity/Total Assets & & & $\begin{array}{c}-0.002 * * * \\
(0.001)\end{array}$ & $\begin{array}{c}-0.002^{* * *} \\
(0.001)\end{array}$ & $\begin{array}{c}-0.015^{* * *} \\
(0.005)\end{array}$ & $\begin{array}{c}-0.015 * * * \\
(0.001)\end{array}$ \\
\hline Deposits/Total Liabilities & & & & $\begin{array}{c}-0.39 \\
(0.378)\end{array}$ & $\begin{array}{c}-0.40 \\
(0.433)\end{array}$ & $\begin{array}{c}-0.42 \\
(0.434)\end{array}$ \\
\hline Real Estate Lending/Total Loans & & & & & $\begin{array}{c}-0.39^{*} \\
(0.228)\end{array}$ & $\begin{array}{l}-0.40^{*} \\
(0.228)\end{array}$ \\
\hline Federal reserve district dummies & & & & & & \\
\hline Boston & & & & & & $\begin{array}{c}-1.20 * * * \\
(0.369)\end{array}$ \\
\hline New York & & & & & & $\begin{array}{c}0.01 \\
(0.375)\end{array}$ \\
\hline Philadelphia & & & & & & $\begin{array}{c}0.370 \\
(0.374)\end{array}$ \\
\hline Cleveland & & & & & & $\begin{array}{c}0.031 \\
(0.288)\end{array}$ \\
\hline Richmond & & & & & & $\begin{array}{l}0.62 * * \\
(0.279)\end{array}$ \\
\hline Atlanta & & & & & & $\begin{array}{c}0.13 \\
(0.235)\end{array}$ \\
\hline Chicago & & & & & & $\begin{array}{c}0.41^{*} \\
(0.232)\end{array}$ \\
\hline St. Louis & & & & & & $\begin{array}{l}0.60 * * \\
(0.244)\end{array}$ \\
\hline Minneapolis & & & & & & $\begin{array}{l}0.56^{* *} \\
(0.241)\end{array}$ \\
\hline Kansas City & & & & & & $\begin{array}{l}0.57 * * \\
(0.230)\end{array}$ \\
\hline Dallas & & & & & & $\begin{array}{c}0.40^{*} \\
(0.240)\end{array}$ \\
\hline Observations & 6,113 & 6,112 & 6,112 & 6,112 & 6,082 & 6,082 \\
\hline R-squared & 0.005 & 0.005 & 0.006 & 0.006 & 0.006 & 0.012 \\
\hline
\end{tabular}

${ }^{\mathrm{a}}$ Estimation is through OLS. Robust standard errors reported in parenthesis. ${ }^{* * *} \mathrm{p}<0.01,{ }^{* *} \mathrm{p}<0.05,{ }^{*} \mathrm{p}<0.1$ 
Table 3: Estimation Output

\begin{tabular}{|c|c|c|c|c|c|c|}
\hline \multirow[b]{2}{*}{ Independent Variables } & \multicolumn{6}{|c|}{ Dependent Variable: Capital-to-assets Ratio ${ }^{a}$} \\
\hline & $(1)$ & $(2)$ & $(3)$ & $(4)$ & $(5)$ & $(6)$ \\
\hline Constant & $\begin{array}{c}9.87 * * * \\
(0.064)\end{array}$ & $\begin{array}{c}9.12 * * * \\
(0.404)\end{array}$ & $\begin{array}{c}9.13 * * * \\
(0.405)\end{array}$ & $\begin{array}{c}9.54 * * * \\
(0.576)\end{array}$ & $\begin{array}{c}9.55^{* * * *} \\
(0.628)\end{array}$ & $\begin{array}{c}8.98 * * * \\
(0.682)\end{array}$ \\
\hline VARCAR & $\begin{array}{c}0.01 * * * \\
(0.002)\end{array}$ & $\begin{array}{c}0.01 * * * \\
(0.002)\end{array}$ & $\begin{array}{c}0.01 * * * \\
(0.002)\end{array}$ & $\begin{array}{c}0.01 * * * \\
(0.002)\end{array}$ & $\begin{array}{c}0.01 * * * \\
(0.002)\end{array}$ & $\begin{array}{c}0.01 * * * \\
(0.002)\end{array}$ \\
\hline Size, $\ln$ (assets) & & $\begin{array}{c}0.07 * \\
(0.033)\end{array}$ & $\begin{array}{c}0.06^{*} \\
(0.033)\end{array}$ & $\begin{array}{c}0.06 \\
(0.035)\end{array}$ & $\begin{array}{l}0.07 * * \\
(0.037)\end{array}$ & $\begin{array}{c}0.07 * \\
(0.037)\end{array}$ \\
\hline Off-balance sheet activity/Total Assets & & & $\begin{array}{c}-0.002 * * * \\
(0.001)\end{array}$ & $\begin{array}{c}-0.003 * * * \\
(0.001)\end{array}$ & $\begin{array}{c}-0.015 * * * \\
(0.005)\end{array}$ & $\begin{array}{c}-0.014 * * * \\
(0.001)\end{array}$ \\
\hline Deposits/Total Liabilities & & & & $\begin{array}{c}-0.40 \\
(0.378)\end{array}$ & $\begin{array}{c}-0.40 \\
(0.433)\end{array}$ & $\begin{array}{c}-0.41 \\
(0.434)\end{array}$ \\
\hline Real Estate Lending/Total Loans & & & & & $\begin{array}{c}-0.37^{*} \\
(0.228)\end{array}$ & $\begin{array}{l}-0.39^{*} \\
(0.227)\end{array}$ \\
\hline Federal reserve district dummies & & & & & & \\
\hline Boston & & & & & & $\begin{array}{c}-1.90 * * * \\
(0.389)\end{array}$ \\
\hline New York & & & & & & $\begin{array}{c}-0.02 \\
(0.375)\end{array}$ \\
\hline Philadelphia & & & & & & $\begin{array}{c}0.331 \\
(0.374)\end{array}$ \\
\hline Cleveland & & & & & & $\begin{array}{c}0.418 \\
(0.286)\end{array}$ \\
\hline Richmond & & & & & & $\begin{array}{c}0.74 * * * \\
(0.282)\end{array}$ \\
\hline Atlanta & & & & & & $\begin{array}{c}0.26 \\
(0.239)\end{array}$ \\
\hline Chicago & & & & & & $\begin{array}{c}0.43 * \\
(0.231)\end{array}$ \\
\hline St. Louis & & & & & & $\begin{array}{l}0.65^{* *} \\
(0.245)\end{array}$ \\
\hline Minneapolis & & & & & & $\begin{array}{l}0.60^{* *} \\
(0.243)\end{array}$ \\
\hline Kansas City & & & & & & $\begin{array}{c}0.70^{* * *} \\
(0.234)\end{array}$ \\
\hline Dallas & & & & & & $\begin{array}{c}0.49 * \\
(0.242)\end{array}$ \\
\hline Observations & 6,113 & 6,112 & 6,112 & 6,112 & 6,082 & 6,082 \\
\hline R-squared & 0.004 & 0.004 & 0.005 & 0.005 & 0.005 & 0.014 \\
\hline
\end{tabular}

${ }^{a}$ Estimation is through OLS. Robust standard errors reported in parenthesis. ${ }^{* * *} \mathrm{p}<0.01, * * \mathrm{p}<0.05, * \mathrm{p}<0.1$ 
Table 4: Estimation output for different cross-sections

\begin{tabular}{|c|c|c|c|c|c|}
\hline Independent Variables & $\begin{array}{l}\text { Dependen } \\
\text { year } 1998\end{array}$ & ariable: Cap & $\begin{array}{l}\text {-to-assets R } \\
\text { Baseline } \\
\text { year } 2000\end{array}$ & year 2001 & year 2002 \\
\hline Constant & $\begin{array}{l}9.10 * * * \\
(0.684)\end{array}$ & $\begin{array}{l}8.84 * * * \\
(0.682)\end{array}$ & $\begin{array}{l}8.71 * * * \\
(0.682)\end{array}$ & $\begin{array}{l}8.97 * * * \\
(0.675)\end{array}$ & $\begin{array}{l}9.10 * * * \\
(0.668)\end{array}$ \\
\hline REPP & $\begin{array}{l}34.46 * * * \\
(9.375)\end{array}$ & $\begin{array}{l}39.76^{* * * *} \\
(9.430)\end{array}$ & $\begin{array}{l}51.86 * * * \\
(9.655)\end{array}$ & $\begin{array}{l}53.49 * * * \\
(9.313)\end{array}$ & $\begin{array}{l}50.21 * * * \\
(9.261)\end{array}$ \\
\hline Size, $\ln$ (assets) & $\begin{array}{l}0.08 * * \\
(0.037)\end{array}$ & $\begin{array}{l}0.08 * * \\
(0.037)\end{array}$ & $\begin{array}{l}0.06^{*} \\
(0.036)\end{array}$ & $\begin{array}{l}0.06 \\
(0.036)\end{array}$ & $\begin{array}{l}0.06^{*} \\
(0.035)\end{array}$ \\
\hline Off-balance sheet activity/Total Assets & $\begin{array}{l}-0.019^{*} \\
(0.010)\end{array}$ & $\begin{array}{l}-0.012 \\
(0.012)\end{array}$ & $\begin{array}{l}-0.014^{* * *} \\
(0.005)\end{array}$ & $\begin{array}{l}-0.013 * * * \\
(0.002)\end{array}$ & $\begin{array}{l}-0.008 * * * \\
(0.001)\end{array}$ \\
\hline Deposits/Total Liabilities & $\begin{array}{l}-0.14 \\
(0.423)\end{array}$ & $\begin{array}{l}-0.35 \\
(0.413)\end{array}$ & $\begin{array}{l}-0.42 \\
(0.434)\end{array}$ & $\begin{array}{l}-0.48 \\
(0.449)\end{array}$ & $\begin{array}{l}-0.27 \\
(0.452)\end{array}$ \\
\hline Real Estate Lending/Total Loans & $\begin{array}{l}-0.563^{* *} \\
(0.224)\end{array}$ & $\begin{array}{l}-0.455^{* *} \\
(0.224)\end{array}$ & $\begin{array}{l}-0.395^{*} \\
(0.228)\end{array}$ & $\begin{array}{l}-0.294 \\
(0.225)\end{array}$ & $\begin{array}{l}-0.662 * * * \\
(0.227)\end{array}$ \\
\hline \multicolumn{6}{|l|}{ Federal reserve district dummies } \\
\hline Boston & $\begin{array}{l}-0.67^{*} \\
(0.384)\end{array}$ & $\begin{array}{l}-0.90^{* *} \\
(0.412)\end{array}$ & $\begin{array}{l}-1.20^{* * *} \\
(0.369)\end{array}$ & $\begin{array}{l}-1.12 * * * \\
(0.345)\end{array}$ & $\begin{array}{l}-0.92 * * \\
(0.369)\end{array}$ \\
\hline New York & $\begin{array}{l}0.39 \\
(0.375)\end{array}$ & $\begin{array}{l}0.07 \\
(0.364)\end{array}$ & $\begin{array}{l}0.01 \\
(0.375)\end{array}$ & $\begin{array}{l}0.09 \\
(0.368)\end{array}$ & $\begin{array}{l}-0.25 \\
(0.342)\end{array}$ \\
\hline Philadelphia & $\begin{array}{l}0.58 \\
(0.355)\end{array}$ & $\begin{array}{l}0.34 \\
(0.367)\end{array}$ & $\begin{array}{l}0.37 \\
(0.374)\end{array}$ & $\begin{array}{l}0.29 \\
(0.349)\end{array}$ & $\begin{array}{l}0.32 \\
(0.378)\end{array}$ \\
\hline Cleveland & $\begin{array}{l}0.44 \\
(0.287)\end{array}$ & $\begin{array}{l}0.25 \\
(0.291)\end{array}$ & $\begin{array}{l}0.03 \\
(0.288)\end{array}$ & $\begin{array}{l}-0.01 \\
(0.281)\end{array}$ & $\begin{array}{l}0.01 \\
(0.271)\end{array}$ \\
\hline Richmond & $\begin{array}{l}0.63^{* *} \\
(0.282)\end{array}$ & $\begin{array}{l}0.49^{*} \\
(0.278)\end{array}$ & $\begin{array}{l}0.62 * * \\
(0.279)\end{array}$ & $\begin{array}{l}0.59 * * \\
(0.275)\end{array}$ & $\begin{array}{l}0.51^{*} \\
(0.265)\end{array}$ \\
\hline Atlanta & $\begin{array}{l}0.20 \\
(0.233)\end{array}$ & $\begin{array}{l}0.05 \\
(0.231)\end{array}$ & $\begin{array}{l}0.13 \\
(0.235)\end{array}$ & $\begin{array}{l}0.25 \\
(0.230)\end{array}$ & $\begin{array}{l}0.27 \\
(0.225)\end{array}$ \\
\hline Chicago & $\begin{array}{l}0.52 * * \\
(0.230)\end{array}$ & $\begin{array}{l}0.37 \\
(0.229)\end{array}$ & $\begin{array}{l}0.41^{*} \\
(0.232)\end{array}$ & $\begin{array}{l}0.60 * * * \\
(0.223)\end{array}$ & $\begin{array}{l}0.60 * * * \\
(0.218)\end{array}$ \\
\hline St. Louis & $\begin{array}{l}0.66 * * * \\
(0.242)\end{array}$ & $\begin{array}{l}0.49^{* *} \\
(0.241)\end{array}$ & $\begin{array}{l}0.60 * * \\
(0.244)\end{array}$ & $\begin{array}{l}0.71 * * * \\
(0.236)\end{array}$ & $\begin{array}{l}0.73 * * * \\
(0.230)\end{array}$ \\
\hline Minneapolis & $\begin{array}{l}0.48^{* *} \\
(0.236)\end{array}$ & $\begin{array}{l}0.43^{*} \\
(0.236)\end{array}$ & $\begin{array}{l}0.56^{* *} \\
(0.241)\end{array}$ & $\begin{array}{l}0.75 * * * \\
(0.233)\end{array}$ & $\begin{array}{l}0.68^{* * *} \\
(0.228)\end{array}$ \\
\hline Kansas City & $\begin{array}{l}0.46^{* *} \\
(0.228)\end{array}$ & $\begin{array}{l}0.43^{*} \\
(0.227)\end{array}$ & $\begin{array}{l}0.57^{* *} \\
(0.230)\end{array}$ & $\begin{array}{l}0.81 * * * \\
(0.224)\end{array}$ & $\begin{array}{l}0.72 * * * \\
(0.220)\end{array}$ \\
\hline Dallas & $\begin{array}{l}0.29 \\
(0.241)\end{array}$ & $\begin{array}{l}0.20 \\
(0.239)\end{array}$ & $\begin{array}{l}0.40^{*} \\
(0.240)\end{array}$ & $\begin{array}{l}0.54 * * \\
(0.231)\end{array}$ & $\begin{array}{l}0.59 * * \\
(0.227)\end{array}$ \\
\hline Observations & 6086 & 6084 & 6082 & 6082 & 6083 \\
\hline R-squared & 0.008 & 0.009 & 0.012 & 0.014 & 0.013 \\
\hline
\end{tabular}

${ }^{\mathrm{a}}$ Estimation is through OLS. Robust standard errors reported in parenthesis. ${ }^{* * *} \mathrm{p}<0.01, * * \mathrm{p}<0.05, * \mathrm{p}<0.1$ 